\title{
SISTEM INFORMASI PELAYANAN PUBLIK DIKECAMATAN KAMPAR TIMUR KABUPATEN KAMPAR
}

\author{
Aguswan \\ Fakultas Ilmu Administrasi Universitas Lancang Kuning \\ Email : aguswan@unilak.ac.id
}

\begin{abstract}
The public information service system, hereinafter referred to as the information system, is a series of activities that include the storage and management of information and mechanisms of delivering information from the organizers to the public and vice versa in the form of oral, latin, written in Braille, image language and / or local languages, And presented manually or electronically. In order to provide information support to the implementation of public services should be held information system that is National. To that end, the organizer is obliged to manage information system which includes: Operator Profile, Executor Profile, Service Standard, Service Notification, Grievance Management and Performance Assessment.The results of the research were conducted in Kampar Timur sub-district office that highlighted the application of public service information system, where the research result stated that the availability of service information system is still incomplete, as many as $14(40,00)$ respondents gave their responses, as well as respondents who responded The implementation of information service system that is as much as $12(34,00)$ respondents gave their responses, and respondents who gave enough response about the implementation of service information system that is $9(26,00)$ respondents who gave the response.Selanjutnya in the implementation of service information system that has been held By Kampar Timur sub-district government, the presence of inhibiting factors is the provision of non-electronic data is still incomplete, tools and technology is still limited and human resources employees who are still less professional in carrying out tasks and His responsibility in carrying out the service to the community.
\end{abstract}

Keywords: Information service system, service standard, implementation

\begin{abstract}
Abstrak
Sistem informasi pelayanan pubik yang selanjutnya di sebut sebagai sistem informasi adalah rangkaian kegiatan yang meliputi penyimpanan dan pengelolaan informasi serta mekanisme penyampaian informasi dari penyelenggara kepada masyarakat dan sebaliknya dalam bentuk lisan, tulisan latin, tulisan dalam huruf Braile, bahasa gambar, dan / atau bahasa lokal, serta disajikan secara manual ataupun elektronik.Dalam rangka memberikan dukungan informasi terhadap penyelenggaraan pelayanan publik perlu diselenggarakan sistem informasi yang bersifat Nasional. Untuk itu penyelenggara berkewajiban mengelola sistem informasi yang meliputi: Profil Penyelenggara, Profil pelaksana, Standar pelayanan, Maklumat pelayanan, Pengelolaan pengaduan dan Penilaian kinerja. Hasil penelitian yang dilaksanakan pada kantor kecamatan Kampar timur yang menyoroti tentang penerapan sistem informasi pelayanan publik, dimana hasil penelitian menyebutkan bahwa ketersediaan system informasi pelayanan masih kurang lengkap yaitu sebanyak $14(40,00)$ responden memberikan tanggapannya, begitu juga responden yang memberikan tanggapanya tentang tersdianya penyelenggaraan system informosi pelayanan yaitu sebanyak 12(34,00) responden memberikan tanggapannya, dan responden yang memberikan tanggapan tentang cukup tersdianya penyelenggaraan system informasi pelayanan yaitu sebanyak 9 $(26,00)$ responden yang memberikan tanggapannya.Selanjutnya dalam penyelenggaraan system informasi pelayanan yang telah diselenggarakan oleh Pemerintahan kecamatan Kampar timur, terdapatnya faktor - faktor penghambat yaitu penyediaan data secara non elektronik masih belum lengkap, alat dan teknologi masih juga terbatas dan SDM pegawai yang masih kurang professional dalam menyelenggarakan tugas dan tanggung jawabnya di dalam melaksanakan pelayanan kepada masyarakat.
\end{abstract}

Kata Kunci : Sistem Informasi Pelayanan, standart pelayanan, implementasi 


\section{PENDAHULUAN}

Pemerintah memiliki peran yang sangat penting sebagai salah satu aktor strategis unuk mewujudkan kesejahteraan masyarakat. Sekalipun tingkat sosial masyarakat telah meningkat peran pemerintah tetap diperlukan untuk melaksanakan fungsi regulasi, alokasi,distribusi,pelayanan dan pemberdayaan masyarakat.fungsi - fungsi ini harus dilaksanakan oleh pemerintah agar tercapai keadilan dan pemerataan dalam masyarakat.Dalam rangka memenuhi kebutuhan masyarakat pemerintah perlu menyelenggarakan pelayanan disetiap sektor publik. Pelayanan publik merupakan kegiatan atau rangkaian kegiatan dalam rangka pemenuhan kebutuhan pelayanan sesuai dengan peraturan perundang undangan bagi setiap warga negara dan penduduk atas barang, jasa, dan/atau pelayanan administratif yang disediakan oleh penyelenggaran pelayanan publik. Maka dari itu Pelayanan publik dilakukan dalam rangka memberikan kepusan bagi pengguna jasa yang membutuhkan layanan yang di inginkan. Kecamatan kampar timur yang menjadi obyek penelitian merupakan sala satu kecamatan dari 21 kecamatan yang berada dalam wilayah kabupaten Kampar Propinsi Riau. Kecamatan kampar Timur merupakan kecamatan yang dimekarkan dari kecamatan induk yakni kecamatan kampar berdasarkan Peraturan daerah Kampar No : 23 tahun 2003 dengan pusat pemerintahan di desa kampar. Kecamatan Kampar timur membawahi 9 Desa diwilayahnya.

Pemerintahan kecamatan kampar timur Kabupaten kampar merupakan sala satu unsur birokrasi yang menyelenggarakan pelayanan kepada masyarakat ditingkat pedesaan, baik itu pelayanan di bidang pemerintahan, pembangunan, ketertiban umum dan pemberdayaan masyarakat. Keseluruhan peran dan fungsi pemerintahan kecamatanharus terwujud dengan baik,sesuai dengan harapan yang di inginkan oleh masyarakat.

Namun persoalan yang ada di kecamatan kampar timur, Aparatur pelaksana kurangmenunjukan kinerjayang baik disaat menyelenggarakan pelayanan kepada masyarakat.Begitu juga dengan standar pelayanan, profil penyelenggara belum tersedia dan hal ini merupakan kewajiban bagi penyelenggara dalam mengelola sistem informasi pelayanan kepada masyarakat baik dalam bentuk eletronik maupun non elektronik.

Sistem informasi pelayanan publik, sebagaimana disebutkan pada UU Pelayanan publik No.12 tahun 2009 yaitu pada pasal 23, disebutkan bahwa penyelenggara berkewajiban mengelola sistem informasi elektronik atau non elektronik, sekurang - kurangnya meliputi:

a.Profil penyelenggara.

b.Profil pelaksana

c.Standar pelayanan

d.Maklumat pelayanan

e.Pengelolaan pengaduan

f.Penilaian kinerja.

Selanjutnya Penetapan standar pelayanan menjadi isu yang sangat penting dalam pengembangan sistem pelayanan publik di negara kesatuan. Standar pelayanan perlu mengatur aspek infut, proses, dan output pelayanan. (Agusdwiyanto,2010:35). Input pelayanan penting untuk distandarisasi mengingat kuantitas dan kualitas dari input pelayanan yang berbeda antar daerah menyebakan sering terjadinya ketimpangan akses terhadap pelayanan yang berkualitas.Standar proses ditetapkan untuk mengatur prinsip dasar penyelenggaraan layanan yaitu penyelenggaraan pelayanan publik harus memenuhi prinsip-prinsip tata pemerintahan yang baik. Danstandar outputdiatur dapat menjamin hak warga dan penduduk dimanapun mereka berda untuk memperoleh kualitas dan kuantitas pelayanan tertentu. 


\section{METODE}

Penelitian dilaksanakan pada kantor pemerintahan kecamatan kampar timur Kabupaten Kampar dengan pendekatan kualitatif. Sedangkan Populasi adalah seluruh pegawai kantorKecamatan Kampar timurdan sekelompok masyarakat yang berkunjung di kantor kecamatan kampar timur. Total keseluruhan sampel atau responden yaitu sebanyak 35 orang

\section{HASIL DAN PEMBAHASAN}

Sistem informasi pelayanan pubik yang selanjutnya di sebut sebagai sistem informasi adalah rangkaian kegiatan yang meliputi penyimpanan dan pengelolaan informasi serta mekanisme penyampaian informasi dari penyelenggara kepada masyarakat dan sebaliknya dalam bentuk lisan, tulisan latin, tulisan dalam huruf Braile, bahasa gambar, dan / atau bahasa lokal, serta disajikan secara manual ataupun elektronik.

Dalam rangka memberikan dukungan informasi terhadap penyelenggaraan pelayanan publik perlu diselenggarakan sistem informasi yang bersifat Nasional. Untuk itu penyelenggara berkewajiban mengelola sistem informasi yang meliputi:ProfilPenyelenggara,Profil pelaksana,Standar pelayanan,Maklumat pelayanan,Pengelolaan pengaduan dan Penilaian kinerja.

Hasil penelitian yang dilaksanakan pada kantor kecamatan Kampar timur yang menyoroti tentang penerapan sistem informasi pelayanan publik, dimana hasil penelitian menyebutkan bahwa ketersediaan system informasi pelayanan masih kurang lengkap yaitu sebanyak $14(40,00)$ responden memberikan tanggapannya, begitu juga responden yang memberikan tanggapanya tentang tersdianya penyelenggaraan system informosi pelayanan yaitu sebanyak 12(34,00) responden memberikan tanggapannya, dan responden yang memberikan tanggapan tentang cukup tersdianya penyelenggaraan system informasi pelayanan yaitu sebanyak $9(26,00)$ responden yang memberikan tanggapannya.

Selanjutnya dalam penyelenggaraan system informasi pelayanan yang telah diselenggarakan oleh Pemerintahan kecamatan Kampar timur, terdapatnya faktor - faktor penghambat yaitu penyediaan data secara non elektronik masih belum lengkap, alat dan teknologi masih juga terbatas dan SDM pegawai yang masih kurang professional dalam menyelenggarakan tugas dan tanggung jawabnya di dalam melaksanakan pelayanan kepada masyarakat.

Untuk dapat mengetahui Peneyelenggaraan sistem informasi yang diselenggarakan oleh Pemerintahan Kecamatan Kampar Timur kabupaten Kampar mka dapat di analisa dan dibahas dalam uraian berikut:

ProfilPenyelenggara merupakan merupakan gambaran umum organisasi atau penyelenggara yang berisikan pada dasar pembentukan organisasi pemerintahan kecamatan kampar timur, keadaan geografis, struktur organisasi, visi dan misi serta tujuan,sasaran program dan kegiatan tahunan yang terukur untuk pembangunan dan pelayanan kepada masyarakat.

Profil penyelengara harus ada dan tergambar dalam pengelolaan sistem informasi pelayanan publik baik dalam bentuk tulisan, gambar yang disediakan dalam manual maupun elektronik.

Dengan demikian dapat disimpulkan bahwa lebih dominan responden memberikan tanggapanya tentang profil penyelenggara telah tersedia sebagai data / file yang digunakan dalam pengelolahaan sistem informasi pelayanan namun masih bersifat manual dan belum secara on line dapat diterapkan di kantor Kecamatan Kampar Timur Kabupaten Kampar.

Profil pelaksana merupakan gambaran atau kondisi para pelaksana (petugas) yang terlibat didalam penyelenggaraan pelayanan publik. Para pegawai (pelaksana) di kantor kecamatan kampar Timur berjumlah 26 orang pegawai yang melaksanakan pelayanan sesuai dengan bidang tugas masing - masing. 
Profil pelaksana harus dikelolah ke dalam sistem informasi yang lebih jelas dan lengkap tersedia secara manual maupun secara eletronik.

Profil pelaksana berisikan tentang identitas pegawai baik dalam bentuk jenis kelamin, pendidikan, golongan kepangkatan, ruang dan jabatan serta usia atau umur pegawai. Keseluruhan data kepegawaian harus tersedia dan tersusun dengan baik. Hal ini sangat membantu organisasi/ penyelanggara kecamatan dalam menentukan karir dan prestasi pegawai. Dalam hal ini gambaran dari profil pelaksana (petugas) merupakan kebutuhan muklak internal penyelenggara untuk menyediakan informasi - informasi yang berhubungan dengan perkembangan pegawai baik secara kuantitatif maupun kualitatif.

Dengan demikian pengelolaan data informasi kepegawaian hanya bersifat manual dan masih disimpan dalam bentuk arsif, tetapi belum di informasi kepada publik dalam bentuk data informasi elektronik, sehingga akses kepegawaian di kantor Kecamatan Kampar timur kurang dapat diwujudkan dalam memenuhi pelayanan publik.

Standar pelayanan merupakan tola ukur yang dipergunakan sebagai pedoman penyelenggaraan pelayanan dan acuan penilaian kualitas pelayanan sebagai kewajiban dan janji penyelenggara kepada masyarakat dalam rangka pelayanan yang berkualitas, cepat, mudah, terjangkau dan terukur.

Dalam penerapan standar pelayanan memerlukn komponen - komponen standar yang merupakan unsur- unsur administrasi dan manajemen dan menjadi bagian dalam sistem dan proses penyelenggaraan pelayanan publik. Berdasarkan pasal 21 UU No.25 tahun 2009, Standar pelayanan mencantumkan komponen - komponen sebagai berikut : (1). Dasar hukum, (2).persyaratan, (3).sistem,mekansme dan prosedur, (4). Jangka waktu penyelesaian, (5) biaya / tarif, (6). Produk layanan, (7). Sarana dan Prasarana, (8).kompotensi pelaksana, (9). Pengawasan internal, (10). Penanganan pengadaduan, saran dan masukan, (11). Jumlah pelaksana, (12). Jaminan Pelayanan, (13) janinan keamanan dan keselamatan pelayanan, (14). Evaluasi Kinerja pelaksana. Keseluruhan komponen - komponen tersebut harus di penuhi oleh penyelenggara pelayanan publik dalam rangka memberikan kemudahan dan kepuasan atas produk dan jasa layanan yang di berikan kepada masyarakat.

Dengan demikian dapat disimpulkan bahwa standar pelayanan yang menyesuaikan pada komponen - komponen pelayanan sebagai mana di amanatkan UU Pelayanan Publik kurang dapat diwujudkan oleh penyelenggara kecamatan, namun pemenuhan kebiutuhan pelayanan masyarakat masih dapat dilaksanakan sesuai dengan kebutuhahan layanan yang inginkan masyarakat kecamatan kampar Timur kabupaten kampar.

Maklumat pelayanan merupakan pernyataan tertulis yang berisi keseluruhan rincian kewajiban dan janji yang terdapat dalam standar pelayanan.Maklumat pelayanan yang dimaksud wajib dipublikasikan secara jelas dan luas.

Hal - hal yang perlu dimuat dalam maklumat pelayanan adalah:

1.Pernyataan janji dan kesanggupan untuk melaksanakan pelayanan sesuai dengan standar pelayanan secara konsisten.

2.Pernyataan kesediaan untuk menerima sanksi apabila memberikan pelayanan tidak sesuai standar pelayanan.

Maklumat pelayanan yang telah disusun wajib dipublikasikan secara luas, jelas, dan terbuka kepada masyarakat melaui berbagai media yang mudah di akases oleh masyarakat

Dengan demikian maklumat pelayanan sebagai janji pelayanan yang diselenggarakan oleh kantor Pemerintahan Kecamatan Kampar Timur kurang dapat diterapkan sebagai mana di amanatkan oleh UU pelayanan Publik No 25 tahun 2009. Dikarenakan pelayanan masih bersifat konvensional dan tidak dapat diakses oleh masyarakat secara luas dan terbuka.

Selanjutnya Penanganan pengaduan, saran dan masukan adalah tata cara pelaksanaan pengelolaan pendaguan tindak lanjut. Merupakan mekanisme pegelolaan pengaduaan, masukan berupa kritikan, saran 
/ usulan dari masyarakat sebagai reaksi terhadap permasalahan yang terjadi dalam penyelenggaraan pelayanan.

Masukan masyarakat sangat penting untuk dikelola secara proposional sebagai bahan untuk koreki dan upayaa perbakan kebijakan pelayanan kedepan. Untuk itu penyelenggara harus menyediakan sarana pengaduan yang mudah di akses oleh masyarakat, dan menunjuk petgas untuk mengelolah dan menindak lanjuti secara tepat. Perlu dikenali faktor - faktor penyebab timbulnya pengaduan/ keluhan masyarakat, antara lain : lemahnya komonikasi, kurang terbuka informasi, lemahnya sistem pencatatan dan dokumentasi, pelayanan yang kurang memudahkan bagi kepentingan atau kebutuhan masyarakat, kurang konsisten petugas dalam menjalankan tugas pekerjaan pelayanan dengan penerapan standar pelayanan dan lainnya.

Dalam pengelolaan pengaduan perlu disiapkan tatacara penanganan atau SOP-nya, disiapkan saranaa pengaduan yang mudah dimamfaatkan masyarakat, seperti : Kotak pendauan, menyiapkan SMS gatewayatau Email, dan perlengkapan lain yang memadai. Nama / judul model atau bentuk dan tatacara pengelolaan pengadun ter4sebut dicantumkan pada format standar pelayanan.

Dengan demikian dapat disimpulkan bahwa pengelolaan pengaduan yang diselenggarakan oleh kantor Kecamatan Kampar Timur masih dalam kategori kurang tersedia atau kurang lengkap, namun pengaduan masyarakat atas saran, kritikan maupun pendapat dilakukan masih secara konvensional tidak menggunakan akses secara terbuka luas dan jelas (online).

Begitu juga dengan Penilaian kinerja (evaluasi kinerja) pelaksana adalah penilaian untuk mengetahui seberapa jauh pelaksanaan kegiatan sesuai dengan standar pelayanan. Tujuanya adalah untuk melihat kembali tingkat keakuratan dan ketepatan penerapan standar pelayanan yang sudah di susun dengan proses penyelenggaraan tugas dan fungsi organisasi, sehingga organisasi dapat berjalan secara efektif dan efisien. Upaya evaluasi di lakukan oleh penyelenggara harus secara priodik dan berkesinambungan guna mengetahui kondisi perkembangan dan mengukur keberhasilan dan/ atau mengetahui hambatan/ kendala yang ditemukan dalam rangka pelaksanaan standar pelayanan.

Penyelenggara di Kantor kecamatan kampar Timur berkewajiban mengelola sistem informasi baik secara elektronik maupun non elektronik yang memuat pada profil penyelenggara, profil pelaksana, standar pelayanan, malumat pelayanan, pengelolaan pengaduan dan penilaian kinerja.

Dari hasil penelitian tersebut dapat juga dijelaskan bahwa profil penyelenggara kecamatan Kampar timur telah disediakan oleh penyelenggara dalam bentuk lisan (manual) atau masuk dalam file kantor, namun profil penyelenggara tersebut belum di akses secara luas dan terbuka, hal ini dikarenakan kondisi kantor kecamatan tidak memilii data Home base yang belum dapat di akses secara On line (internet)kepada masyarakat luas di kecamatan Kampar timur Kabupaten Kampar. Berdasarkan hasil penelitian yang dilaksanakan di Kantor kecamatan Kampar timur kabupaten Kampar, dimana dalam penyelenggaraan sistem informasi pelayanan publik terdapat beberapa faktor penghambat di antaranya :

1.Penyediaan data secara non elektronik masih belum lengkap.

2.ketersedian alat dan teknologi (elektronik)masih terbatas.

3.SDM aparatur kurang Profesional.

\section{KESIMPULAN}

Dari hasil penelitian yang dilaksanakan di Kecamatan Kampar Timur Kabupaten Kampar menyoroti pada Penyelenggaraan Sistem Informasi Pelayanan publik,maka dari itu hasil penelitian dapat disimpulkan berikut ini.

1. 1.Penerapan sistem informasi pelayanan publik di kecamatan kampar timur kabupaten kampar dimana pengelolaan sistem informasi yang dilaksanakan berada dalam kategori kurang lengkap, 
yaitu sebanyak $14(40,00)$ orang responden memberikan tanggapannya bahwa kurang tersdinya informasi pelayanan secara l;engkap dan luas.

2. 2.Penerapan sistem informasi pelayanan publik di kecamatan kampar timur terdapat beberapa kendala atau faktor penghambat yaitu :

a. Penyediaan data secara non elektronik masih belum lengkap.

b. ketersedian alat dan teknologi (elektronik) masih terbatas.

c. SDM aparatur kurang Profesional.

\section{DAFTAR PUSTAKA}

[1]. Agusdwiyanto, 2010, manajemen pelayanan public : peduli inklusif dan kalaboratif, UGM, Yogyakarta.

[2]. Ateb Adya Brata, 2013, dasar - dasar pelayanan Prima, PT.ELex Media komputindo kelompok gramedia, Jakarta.

[3]. Dede mariana, 2010 merancang reformasi Birokrasi di Indonesia, AIPI bandung.

[4]. Dedi Mulyadi, 2015, studi kebijakan publik dan pelayanan publik, alfabeta bandung.

[5]. Harbani Pasolong, 2010, teori Administrasi Publik, Alfabeta bandung.

[6]. Peraturan Pemerintah RI.No.96 tahun 2012 tentang Pelaksanaan UU.No 25 tahun 2009.

[7]. Permenpan RB No,36 tahun 2012 tentang petunjuk teknis penyusunan, penetapan dan penerapan standarpelayanan.

[8]. Saputra, T., \& Marlinda, P. (2017). Capaian Pelayanan Kesehatan Dasar Di Kota Pekanbaru. Jurnal Ilmu Sosial Mamangan, 5(2), 79-88.

[9]. Sinta Ningrum, 2011, Trasnformasi administrasi Negara : Perspektif manajerialisme, falsafah Jakarta.

[10]. UU Pelayanan Publik No25 tahun 2009, edisi terbaru, Fokusisndo Mandiri Bandung.

[11]. Zulkipli Amsyah (2011), manajemen system informasi, Gramedia Pustaka Utama, Jakarta. 